\title{
Global radiation by simplified models for the state of Mato Grosso, Brazil
}

\author{
Adilson Pacheco de Souza(1), Andréa Carvalho da Silva(1), Adriana Aki Tanaka(1), Eduardo Morgan Uliana(1), \\ Frederico Terra de Almeida ${ }^{(1)}$, Antonio Evaldo $\mathrm{Klar}^{(2)}$ and Anthony Wellington Almeida Gomes ${ }^{(3)}$
}

\begin{abstract}
(1)Universidade Federal de Mato Grosso, Campus Sinop, Instituto de Ciências Agrárias e Ambientais, Avenida Alexandre Ferronato, no 1.200, Setor Industrial, CEP 78557-267 Sinop, MT, Brazil. E-mail: pachecoufmt@gmail.com, acarvalho@ufmt.br, dritanak@hotmail.com, morganuliana@gmail.com, freterr@gmail.com (2)Universidade Estadual Paulista Júlio de Mesquita Filho, Faculdade de Ciências Agronômicas de Botucatu, Departamento de Engenharia Rural, Fazenda Lageado, Rua José Barbosa de Barros, № 1.780, CEP 18610-307 Botucatu, SP, Brazil. E-mail: klar@fca.unesp.br ${ }^{(3)}$ Universidade Federal Rural do Pernambuco, Unidade Acadêmica de Garanhuns, Avenida Bom Pastor, s/no, Boa Vista, CEP 55292-270 Garanhuns, PE, Brazil. E-mail: awagomes@uag.ufrpe.br
\end{abstract}

Abstract - The objective of this work was to estimate the global radiation by simplified models for the state of Mato Grosso, Brazil. The parameterized coefficients of 15 simplified models were regionally calibrated to estimate the daily global radiation, based only on air temperature, using data from 28 automatic weather stations (AWS) of the network of the Brazilian Meteorology Institute, distributed throughout the different biomes of the state of Mato Grosso. The simplified models are mostly derived from the Hargreaves and Bristow \& Campbell methods, with different parameterized coefficients to be calibrated. The coefficient of determination $\left(\mathrm{R}^{2}\right)$, the mean bias error (MBE), the root mean square error (RMSE), and Willmott's $d$ index were used to evaluate statistical performance. For the recommendation of models per station and/or biome, the models were rated numerically (position values) according to their specific performance in each statistical indicator. The simplified models derived from Bristow \& Campbell showed better statistical performances for estimating daily global radiation. The values of the calibrated coefficients of the same model varied greatly among the AWS and biomes. The $\mathrm{R}^{2}$ values ranged from 0.60 to 0.75 , indicating a satisfactory result for the obtained calibrations. The Bristow \& Campbell model for the Amazon and the Cerrado and the Goodin model for the Cerrado are recommended, with scattering varying between 1.52 and $4.33 \mathrm{MJ} \mathrm{m}^{-2}$ per day and adjustments greater than $65 \%$.

Index terms: air temperature, Amazon, Cerrado, parameterized coefficients, solar radiation.

\section{Radiação global por modelos simplificados para o Estado de Mato Grosso}

\begin{abstract}
Resumo - O objetivo deste trabalho foi estimar a radiação global por modelos simplificados para o Estado de Mato Grosso. Os coeficientes parametrizados de 15 modelos simplificados foram regionalmente calibrados para estimativa da radiação global diária, com base apenas na temperatura do ar, a partir de dados de 28 estações meteorológicas automáticas (EMAs) da rede do Instituto Nacional de Meteorologia, distribuídas nos diferentes biomas do Estado de Mato Grosso. Os modelos simplificados avaliados foram derivados principalmente dos métodos de Hargreaves e Bristow \& Campbell, com diferentes coeficientes parametrizados a serem calibrados. Para a avaliação do desempenho estatístico, foram empregados o coeficiente de determinação $\left(\mathrm{R}^{2}\right)$, o erro absoluto médio (MBE), a raiz quadrada do erro quadrático médio (RMSE) e o índice d de Willmott. Para a recomendação de modelos por estação e/ou bioma, os modelos foram classificados numericamente (valores de posição), de acordo com o desempenho específico em cada indicativo estatístico. Os modelos simplificados derivados de Bristow \& Campbell apresentaram melhores desempenhos estatísticos para estimativa da radiação global diária. Os valores dos coeficientes calibrados de um mesmo modelo variaram grandemente entre as EMAs e os biomas. Os valores do $\mathrm{R}^{2}$ variaram de 0,60 a 0,75 , o que indica resultados satisfatórios nas calibrações obtidas. São indicados o modelo de Bristow \& Campbell para a Amazônia e o Cerrado e o de Goodin para o Cerrado, com espalhamentos que variam entre 1,52 e 4,33 MJ m por dia e ajustamentos superiores a $65 \%$.
\end{abstract}

Termos para indexação: temperatura do ar, Amazônia, Cerrado, coeficientes parametrizados, radiação solar.

\section{Introduction}

There is a rising interest in the research field of solar irradiation due to its many applications in the physical, chemical, and biological processes that occur in the biosphere-atmosphere interaction. The knowledge of seasonal and temporal variations allow its use in 
studies on evapotranspiration, optimization of water demand in irrigation, crop forecasting, agricultural planning, climate change, development of energy technology systems (thermal and photovoltaic), food preservation, buildings and ambiance, among others (Antonanzas-Torres et al., 2013; Dumas et al., 2015; Huber et al., 2016).

Geographic, astronomical, meteorological, geometric, and biophysical factors - such as the dispersion of air molecules, water vapor content in the atmosphere, dust scattering, and other atmospheric constituents, including $\mathrm{O}_{2}, \mathrm{CO}_{2}$, and $\mathrm{N}_{2}$ - affect the amount of solar radiation that reaches Earth's surface and are typically used as the basis of empirical models (Badescu, 2013; Teke et al., 2015; Huber et al., 2016).

In Brazilian meteorological researches, after the diffusion of automatic weather stations (AWS), there has been a significant increase in the routine measurements of solar radiation. However, in some regions, such as in the state of Mato Grosso, there is a low spatial distribution of AWS that measure solar radiation. In general, the routine monitoring of solar radiation is carried out by Instituto Brasileiro de Meteorologia (Inmet), universities, and research institutes, depending on the costs involved in acquiring and/or maintaining the instruments. For hydro-agricultural applications, the use of long-time databases is essential; however, when these are dependent on solar radiation, they can only be obtained by estimates of and applications on historical series of conventional weather stations (normal climatology).

In this context, the high cost of measuring solar irradiation with a pyranometer and the scarcity of long, reliable datasets for specific locations has encouraged the use of simplified estimators, including models based on air temperature, air humidity, precipitation, sky cover (clouds), sunshine fraction, linear regression, geostationary satellite data, stochastic models, artificial neural networks, among others (Gueymard \& Myers, 2009; Antonanzas-Torres et al., 2013; Bojanowski et al., 2013; Veeraboina \& Guduri, 2014; Yacef et al., 2014; Dumas et al., 2015; Teke et al., 2015).

Air temperature, sunshine fraction, and precipitation are the meteorological parameters with greater abundance and spatial distribution in databases; therefore, they are the most commonly adopted in the simplified models used to estimate global radiation for different climatic regions and/or temporal scales (Besharat et al., 2013; Bojanowski et al., 2013; Veeraboina \& Guduri, 2014; Yacef et al., 2014; Dumas et al., 2015). However, the accuracy of these models may vary when applied in different locations, requiring local/regional calibrations of the parameterized coefficients (Teke et al., 2015; Huber et al., 2016).

The objective of this work was to estimate the global radiation by simplified models for the state of Mato Grosso, Brazil.

\section{Materials and Methods}

The data used were obtained from the AWS of Inmet located in 28 municipalities of the state of Mato Grosso, Brazil (Table 1). The installation, operation, and maintenance of the AWS, as well as the availability of their databases, are described by Moura et al. (2011). It should be noted that, although the network of stations in Mato Grosso is formed by 35 AWS, some of them were disregarded in the present study due to flaws and to the lack of data, which were related to equipment failures and/or calibration, to the lack of maintenance, or to the fact they were closed. Since the stations began operating on different dates in each municipality, the periods of data collection varied. Of the daily database, 70 and 30\% were used for calibration and validation, respectively.

The state of Mato Grosso is located in the Midwestern region of Brazil $\left(06^{\circ} 00^{\prime} \mathrm{S}, 1^{\circ} 45^{\prime} \mathrm{S}\right.$ and $50^{\circ} 06^{\prime} \mathrm{W}$, $62^{\circ} 45^{\prime} \mathrm{W}$ ), totaling $903,357.908 \mathrm{~km}^{2}$, which represent $56.23 \%$ of the region and $10.61 \%$ of the entire Brazilian territory. The state stands out for its large territorial extension and insertion into the natural landscape of three major biomes: Amazon rainforest, Cerrado, and Pantanal (Figure 1), which provide a wide range of ecological, social, economic, cultural, and production/ agro-industrial development situations.

Two well-defined seasons occur in the state of Mato Grosso: rainy, from October to April; and dry, from May to September. The average annual temperatures range between 23 and $26.84^{\circ} \mathrm{C}$ and total annual rainfall varies from 1,200 to $2,000 \mathrm{~mm}$, with higher levels in the north and east-north of the state and in regions with altitudes close to $800 \mathrm{~m}$. The climate is classified as Aw (tropical savanna climate) and as Cwa (tropical climate), according to Köppen (Souza et al., 2013).

The following 15 simplified models, mostly derived from those proposed by Hargreaves (1981) and Bristow \& Campbell (1984), were used to estimate global 
radiation, with different demands for the calibration of the parameterized coefficients:

1. ABS (Abraha \& Savage, 2008)

$$
\mathrm{H}_{\mathrm{G}}=0.75\left(1-\exp \left(-\mathrm{b} \frac{\Delta \mathrm{T}^{2}}{\Delta \mathrm{T}_{\mathrm{MED}}}\right)\right) \mathrm{H}_{0}
$$

2. ASW (Weiss et al., 2001; Abraha \& Savage, 2008)

$$
\mathrm{H}_{\mathrm{G}}=0.75\left(1-\exp \left(-\mathrm{b} \mathrm{f}\left(\mathrm{T}_{\mathrm{MED}}\right) \Delta \mathrm{T}^{2} \mathrm{f}\left(\mathrm{T}_{\mathrm{MED}}\right)\right)\right) \mathrm{H}_{0}
$$

$\mathrm{f}\left(\mathrm{T}_{\mathrm{MED}}\right)=0.017 \exp \left(-0.053 \mathrm{~T}_{\text {MED }}\right) ; \mathrm{f}\left(\mathrm{T}_{\mathrm{MIN}}\right)=\exp \left(\mathrm{T}_{\text {MIN }} /\right.$ tnc $)$

3. ALM (Almorox et al., 2011)

$$
\mathrm{H}_{\mathrm{G}}=\mathrm{a} \Delta \mathrm{T}^{\mathrm{b}}\left(1-\exp \left(-\mathrm{c}\left(\mathrm{es}_{\min } / \mathrm{es}_{\max }\right)^{\mathrm{d}}\right)\right) \mathrm{H}_{0}
$$

4. ANN (Annandale et al., 2002)

$$
\mathrm{H}_{\mathrm{G}}=\mathrm{a}\left(1+2.7 \times 10^{-5} \text { Alt }\right) \sqrt{\Delta \mathrm{T}} \mathrm{H}_{0}
$$

5. BRC (Bristow \& Campbell, 1984)

$$
\mathrm{H}_{\mathrm{G}}=\mathrm{a}\left(1-\exp \left(-\mathrm{b} \Delta \mathrm{T}^{\mathrm{c}}\right)\right) \mathrm{H}_{0}
$$

6. CHE (Chen et al., 2004)

$$
\mathrm{H}_{\mathrm{G}}=(\mathrm{a} \sqrt{\Delta \mathrm{T}}+\mathrm{b}) \mathrm{H}_{0}
$$

7. DJS (De Jong \& Stewart, 1993)

$$
\mathrm{H}_{\mathrm{G}}=\mathrm{a} \Delta \mathrm{T}^{\mathrm{b}}\left(1+\mathrm{cP}+\mathrm{dP}^{2}\right) \mathrm{H}_{0}
$$

8. DOC (Donatelli \& Campbell, 1998)

$$
\mathrm{H}_{\mathrm{G}}=\mathrm{a}\left(1-\exp \left(-\mathrm{b} \frac{\Delta \mathrm{T}^{\mathrm{c}}}{\Delta \mathrm{T}_{\text {MED }}}\right)\right) \mathrm{H}_{0}
$$

9. GOO (Goodin et al., 1999)

$$
\mathrm{H}_{\mathrm{G}}=\mathrm{a}\left(1-\exp \left(-\mathrm{b} \frac{\Delta \mathrm{T}^{\mathrm{c}}}{\mathrm{H}_{0}}\right)\right) \mathrm{H}_{0}
$$

\section{HAR (Hargreaves, 1981)}

$$
\mathrm{H}_{\mathrm{G}}=\mathrm{a}\left(\mathrm{T}_{\mathrm{MAX}}-\mathrm{T}_{\mathrm{MIN}}\right)^{0.5} \mathrm{H}_{0}
$$

11. HU1 (Hunt et al., 1998)

$$
\mathrm{H}_{\mathrm{G}}=\mathrm{a} \sqrt{\Delta \mathrm{T}} \mathrm{H}_{0}+\mathrm{b}
$$

Table 1. Automatic weather stations of the network of Instituto Nacional de Meteorologia (Inmet), from where the data used to estimate daily global radiation were collected, located in the state of Mato Grosso, Brazil.

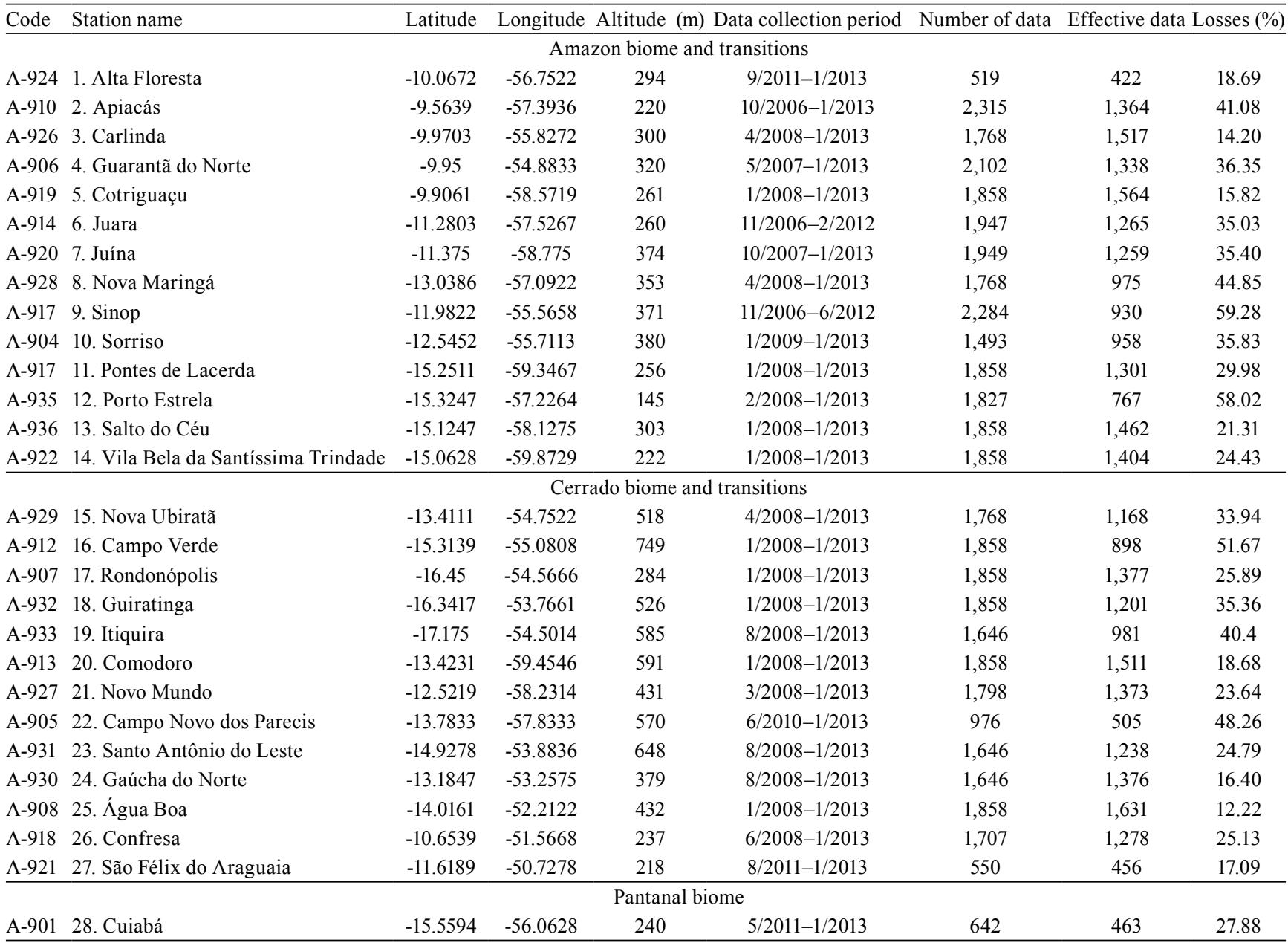


12. HU2 (Hunt et al., 1998)

$$
\mathrm{H}_{\mathrm{G}}=\mathrm{a} \sqrt{\Delta \mathrm{T}} \mathrm{H}_{0}+\mathrm{bT}_{\mathrm{MAX}}+\mathrm{cP}+\mathrm{dP}^{2}+\mathrm{e}
$$

13. MAH (Mahmood \& Hubbard, 2002)

$$
\mathrm{H}_{\mathrm{G}}=\mathrm{a} \Delta \mathrm{T}^{0.69} \mathrm{H}_{0}^{0.91}
$$

14. MEV (Meza \& Varas, 2000)

$$
\mathrm{H}_{\mathrm{G}}=0.75\left(1-\exp \left(-\mathrm{b} \Delta \mathrm{T}^{2}\right)\right) \mathrm{H}_{0}
$$

15. THR (Thornton \& Running, 1999)

$$
\mathrm{HG}=\mathrm{H}_{0}\left(1-0.9 \exp \left(-\mathrm{b} \Delta \mathrm{T}^{1.5}\right)\right)
$$

in which $\Delta \mathrm{T}$ is the thermal amplitude; $\mathrm{T}_{\text {med }}$ is the average air temperature; $T_{\min }$ is the minimum air temperature; $\mathrm{T}_{\max }$ is the maximum air temperature; $\mathrm{es}_{\min }$ is the minimum vapor saturation pressure; $\mathrm{es}_{\max }$ is the maximum vapor saturation pressure; Alt is the local altitude; $\mathrm{P}$ is precipitation; tnc is the factor temperature of summer nights; $\mathrm{H}_{0}$ is the daily global solar radiation on the horizontal surface $\left(\mathrm{MJ} \mathrm{m}^{-2}\right.$ per day); and a, b, and c are the parameterized coefficients to be calibrated regionally.

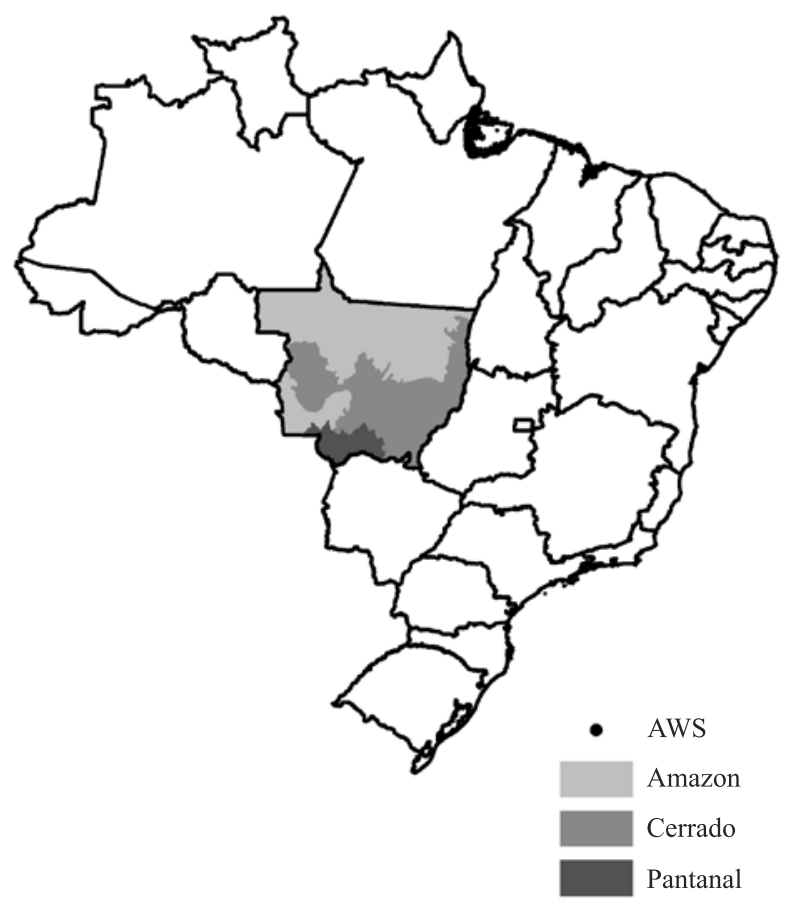

The coefficients of the equations were adjusted using the solver optimization tool of Microsoft Excel, based on the maximization of the coefficient of determination $\left(\mathrm{R}^{2}\right)$. To assess the performance of the equations for daily estimates on sloping and horizontal surfaces, the statistical indicators $\mathrm{R}^{2}$, mean bias error (MBE), root mean square error (RMSE), and Willmott's adjustment $\mathrm{d}$ index were employed, as recommended by Souza et al. (2011), Badescu (2013), and Teke et al. (2015), using the following equations:

$$
\begin{aligned}
& \text { MBE }=\sum_{\mathrm{i}-1}^{\mathrm{N}}\left(\mathrm{P}_{\mathrm{i}}-\mathrm{O}_{\mathrm{i}}\right) / \mathrm{N}-1 ; \\
& \mathrm{RMSE}=\left[\sum_{\mathrm{i}=1}^{\mathrm{N}}\left(\mathrm{P}_{\mathrm{i}}-\mathrm{O}_{\mathrm{i}}\right)^{2} / \mathrm{N}\right]^{0.5} ; \\
& \mathrm{d}=\left[\sum_{\mathrm{i}=1}^{\mathrm{N}}\left(\mathrm{P}_{\mathrm{i}}-\mathrm{O}_{\mathrm{i}}\right)^{2} / \sum\left(\left|\mathrm{P}_{\mathrm{i}}-\mathrm{O}\right|+\left|\mathrm{O}_{\mathrm{i}}-\mathrm{O}\right|\right)^{2}\right]
\end{aligned}
$$

in which $\mathrm{P}_{\mathrm{i}}$ are the estimated values; $\mathrm{O}_{i}$ are the measured values; $\mathrm{N}$ is the number of observations; $\left|\mathrm{P}_{\mathrm{i}}\right|$ is the absolute value of the difference $\left(\mathrm{P}_{\mathrm{i}}-\mathrm{O}_{\mathrm{i}}\right)$; and $\left|\mathrm{O}_{\mathrm{i}}\right|$

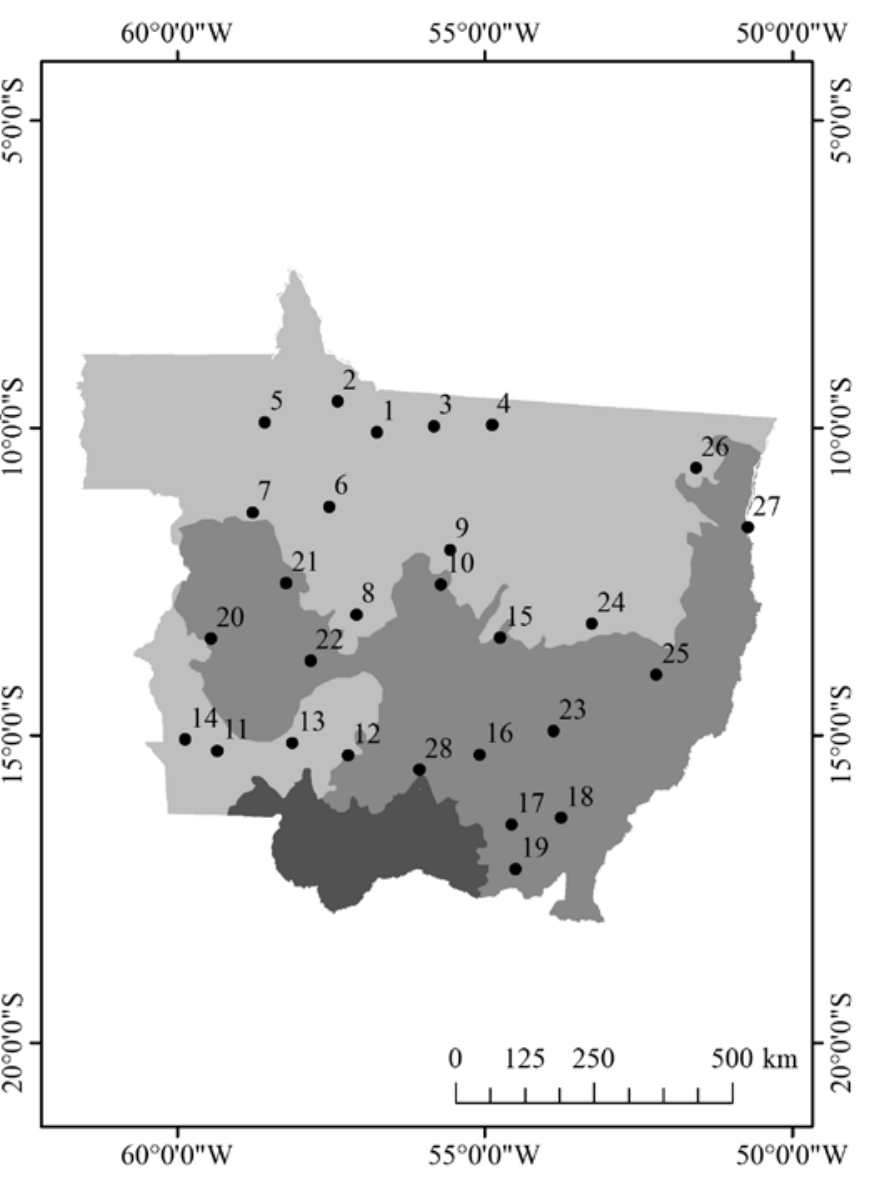

Figure 1. Biomes of the state of Mato Grosso, Brazil, and location of the automatic weather stations (AWS). Numerical identification according to Table 1. 
is the absolute value of the difference $\left(\mathrm{P}_{\mathrm{i}}-\mathrm{O}_{\mathrm{i}}\right)$. In these cases, $\mathrm{i}$ ranges from 1 to $\mathrm{N}$.

Then, the position values (Vp) of the statistical indicators $\left(\mathrm{R}^{2}, \mathrm{MBE}, \mathrm{RMSE}\right.$, and Willmott's adjustment $\mathrm{d}$ index), based on their assigned weights, were used to classify and to define the best model for estimating global radiation. The models were classified from 1 to 15 for each weather station, according to the $\mathrm{Vp}$ of the indicators. In this case, 1 represents the best model and 15 the worst one; consequently, the best model is the one with the lowest sum of assigned weights, i.e., with lower Vp accumulated for all statistical indicators.

\section{Results and Discussion}

Due to the geographical location and rainfall behavior of the state of Mato Grosso, the global radiation measured in the Amazon and Cerrado biomes showed similar averages, i.e., $18.05 \pm 1.08$ and $18.57 \pm 1.41 \mathrm{MJ} \mathrm{m}^{-2}$ per day, respectively (Table 2). According to Souza et al. (2013), seasonal changes in cloudiness and latitude are the main factors that determine the variation of solar radiation in the state. The averages obtained for the periods in which the data from the AWS were analyzed are in alignment with those of other studies carried out in the evaluated biomes (Tiba, 2000); this includes the lower global radiation values observed at the weather station located in the municipality of Cuiabá (14.18 $\mathrm{MJ} \mathrm{m}^{-2}$ per day), when compared with those of the other regions (Gomes et al., 2012).

Overall, the values of the calibrated coefficients of the same model varied greatly among the AWS and biomes (Table 3). In this case, the R2 also shows the high adjustment variability of the models within the same biome, resulting from changes in air temperature, which varies temporally and spatially due to energy balance, local weather and environment (configuration of surface exposure, land use and occupation, among others).

These results, including discrepancies, are in alignment with those found in the literature for regional models with different calibrations. According to Meza \& Varas (2000), these differences indicate that the local calibration for some simplified models can be crucial for their performance; however, most of the proposed coefficients in the literature did not correctly estimate the historical averages in each location. Weiss et al. (2001) pointed out that adjustments or calibrations of the coefficients of the empirical models for each municipality allow finding a specific coefficient that best fits the environmental conditions of the site, which reduces the average error of the differences between the estimated and measured values of solar radiation.

The $\mathrm{R}^{2}$ is one of the first indicators of the statistical performance of estimation models, but requires other valuation parameters (Teke et al., 2015). According to Souza et al. (2011), the combined use of the statistical indicators MBE, RMSE, and the adjustment $\mathrm{d}$ index provides an adequate alternative for the validation of statistical models with the simultaneous analysis of deviations from the mean, identifying the occurrence of under- or overestimation, spreading, and model adjustment in relation to the measured values.

In general, the $\mathrm{R}^{2}$ values ranging from 0.60 to 0.75 indicate satisfactory results for calibration proposals, as found by Borges et al. (2010) for the municipality of Cruz das Almas, in the state of Bahia, Brazil. However, these results were lower than those reported by Silva et al. (2012) for different regions of the state of Minas Gerais, also in Brazil, and for the original models evaluated.

Good performances are normally expected when databases from regions climatically similar to those of the original models are used. It should also be noted that the size of the database affects the obtained results, since calibrations and/or performance reviews carried out with data obtained during years of air maximum and minimum temperatures can occur in atypical years, with effects from other external phenomena of the region.

The ALM, DJS, and HU2 models with calibration coefficients for rainfall dependence showed that this variable made it difficult to estimate solar radiation due to the low $\mathrm{R}^{2}$ values, as observed by Liu et al. (2009) and Silva et al. (2012). This could be attributed to measurement errors in the rainfall monitoring equipment and/or to errors in bug fixes, particularly for regions with high temporal and spatial variability in rainfall events of convective origin (Souza et al., 2013).

There were no trends of super- or underestimation by biomes; however, a great discrepancy was observed between the MBE values of the same model for the AWS (Table 4). There is a major drawback in analyzing the MBE in isolation, as the underestimation of a single observation can undo an overestimation of another one (Souza et al., 2011; Badescu, 2013; Teke et al., 2015). 
The scattering between the measured and estimated values (RMSE) ranged from 1.52 to $4.58 \mathrm{MJ}$ m-2 per day (Table 5), with best results obtained with the BRC and GOO models. Figure 2 shows the correlation behavior of these two models at the weather station of the municipality of Sinop. In this case, due to temporal partition, these values were lower than those found by Goodin (1999) in the United States and by Silva et al. (2012) under the climatic conditions of the state of Minas Gerais, but were similar to those reported by Liu et al. (2009) and Almorox et al. (2011) under the climatic conditions of China and Spain, respectively.
Willmott's $d$ index shows the accuracy degree of the measured and estimated values, for which most models (ASW, ALM, ANN, BRC, CHE, DJS, DOC, GOO, HAR, HU1, and HU2) obtained satisfactory results, with adjustment values ranging from 0.80 to 0.90 (Table 6). These results are in alignment with those found by Silva et al. (2012) in the northwest of Minas Gerais.

Considering the Vp accumulation for three of the statistical indicators evaluated in each weather station, the models that showed the best statistical performance for 57.14 and $17.85 \%$ of the analyzed stations were BRC

Table 2. Daily global radiation (HG) measured and estimated by 15 simplified models using data from 28 automatic weather stations located in the state of Mato Grosso, Brazil ${ }^{(1)}$.

\begin{tabular}{|c|c|c|c|c|c|c|c|c|c|c|c|c|c|c|c|c|}
\hline \multirow{2}{*}{\multicolumn{2}{|c|}{$\begin{array}{c}\text { Station } \mathrm{H}_{\mathrm{G}}\left(\mathrm{MJ} \mathrm{m}^{-2}\right. \\
\text { per day })\end{array}$}} & \multicolumn{15}{|c|}{ Simplified models } \\
\hline & & ABS & ASW & ALM & ANN & BRC & CHE & DJS & DOC & GOO & HAR & HU1 & HU2 & MAH & MEV & THR \\
\hline \multicolumn{17}{|c|}{ Amazon biome and transitions } \\
\hline A-924 & 18.05 & 19.26 & 19.22 & 19.09 & 18.70 & 18.71 & 18.73 & 18.78 & 18.44 & 18.54 & 19.09 & 18.68 & 18.79 & 19.30 & 19.17 & 19.28 \\
\hline A-910 & 17.72 & 18.24 & 17.84 & 18.26 & 17.65 & 17.84 & 17.76 & 17.84 & 17.69 & 17.66 & 17.65 & 17.67 & 17.67 & 17.67 & 18.14 & 17.75 \\
\hline A-926 & 18.98 & 19.01 & 18.86 & 18.89 & 18.70 & 18.75 & 19.26 & 18.58 & 18.62 & 18.69 & 18.70 & 18.79 & 18.88 & 18.71 & 19.03 & 18.74 \\
\hline A-906 & 16.72 & 17.93 & 16.48 & 16.59 & 16.55 & 16.54 & 17.79 & 17.41 & 17.57 & 18.30 & 16.15 & 16.56 & 17.05 & 16.39 & 17.33 & 16.34 \\
\hline A-919 & 17.10 & 17.31 & 17.08 & 17.06 & 16.96 & 17.00 & 17.03 & 17.37 & 16.88 & 16.92 & 16.96 & 16.82 & 16.96 & 16.99 & 17.30 & 17.01 \\
\hline A-914 & 17.76 & 18.52 & 17.85 & 18.01 & 17.71 & 17.78 & 17.76 & 17.84 & 17.82 & 17.79 & 17.75 & 17.73 & 17.96 & 17.60 & 18.44 & 17.68 \\
\hline A-920 & 17.58 & 17.98 & 17.49 & 17.67 & 17.43 & 17.49 & 17.55 & 17.45 & 17.46 & 17.47 & 17.43 & 17.53 & 17.52 & 17.38 & 17.92 & 17.40 \\
\hline A-928 & 16.87 & 17.25 & 16.83 & 16.78 & 16.26 & 16.75 & 16.44 & 16.76 & 16.49 & 16.51 & 16.26 & 16.42 & 16.65 & 16.51 & 17.11 & 16.62 \\
\hline A-917 & 21.03 & 21.23 & 21.25 & 21.28 & 21.21 & 21.26 & 21.08 & 21.16 & 21.18 & 20.93 & 22.18 & 21.39 & 0.00 & 0.00 & 0.00 & 0.00 \\
\hline A-904 & 18.02 & 18.09 & 18.13 & 18.04 & 17.78 & 17.93 & 18.46 & 18.19 & 17.67 & 17.71 & 17.78 & 17.87 & 18.33 & 18.02 & 18.10 & 18.02 \\
\hline A-917 & 18.71 & 18.69 & 18.79 & 18.68 & 18.43 & 18.62 & 18.99 & 18.44 & 18.31 & 18.31 & 18.43 & 18.41 & 18.72 & 18.63 & 18.65 & 18.67 \\
\hline A-935 & 17.93 & 17.41 & 18.89 & 19.09 & 17.43 & 17.95 & 17.57 & 18.26 & 17.61 & 17.65 & 17.43 & 17.55 & 17.68 & 17.24 & 18.85 & 16.60 \\
\hline A-936 & 17.61 & 17.47 & 17.63 & 17.46 & 17.26 & 17.42 & 17.67 & 17.61 & 17.13 & 17.20 & 17.26 & 17.25 & 17.68 & 17.35 & 17.41 & 17.33 \\
\hline A-922 & 18.66 & 18.91 & 18.97 & 18.80 & 18.43 & 18.71 & 18.57 & 18.70 & 18.35 & 18.47 & 18.45 & 18.80 & 19.15 & 18.70 & 18.88 & 18.81 \\
\hline \multicolumn{17}{|c|}{ Cerrado biome and transitions } \\
\hline A-929 & 19.10 & 19.40 & 19.42 & 19.26 & 19.10 & 19.21 & 19.19 & 19.06 & 19.02 & 19.04 & 19.10 & 19.37 & 19.25 & 19.07 & 19.45 & 19.12 \\
\hline A-912 & 20.50 & 20.68 & 20.89 & 21.07 & 20.44 & 21.07 & 21.15 & 21.22 & 21.19 & 21.25 & 19.69 & 19.66 & 20.90 & 20.09 & 19.79 & 20.22 \\
\hline A-907 & 18.36 & 18.82 & 17.28 & 17.97 & 17.33 & 17.30 & 17.60 & 17.54 & 17.99 & 18.04 & 17.33 & 17.81 & 18.40 & 17.01 & 18.78 & 17.09 \\
\hline A-932 & 15.50 & 15.77 & 15.28 & 15.27 & 15.37 & 15.18 & 15.39 & 15.22 & 15.36 & 15.39 & 15.37 & 15.34 & 15.18 & 15.15 & 15.73 & 15.10 \\
\hline A-933 & 19.81 & 19.67 & 19.68 & 18.30 & 19.47 & 18.66 & 20.08 & 20.05 & 19.35 & 19.52 & 19.47 & 19.47 & 20.03 & 19.36 & 19.76 & 19.36 \\
\hline A-913 & 18.09 & 18.09 & 17.88 & 17.90 & 17.78 & 17.83 & 17.98 & 18.36 & 17.69 & 17.78 & 17.78 & 17.77 & 17.95 & 17.70 & 18.02 & 17.72 \\
\hline A-927 & 19.27 & 19.29 & 19.25 & 19.06 & 18.91 & 19.00 & 18.74 & 18.80 & 18.88 & 18.93 & 18.91 & 19.01 & 19.07 & 18.93 & 19.34 & 19.00 \\
\hline A-905 & 16.33 & 17.43 & 16.69 & 16.60 & 16.51 & 16.54 & 16.53 & 16.71 & 16.45 & 16.53 & 16.47 & 16.51 & 16.63 & 16.55 & 16.90 & 16.51 \\
\hline A-931 & 20.13 & 20.33 & 20.44 & 20.24 & 19.98 & 20.18 & 20.18 & 20.40 & 19.94 & 19.95 & 19.98 & 20.28 & 20.24 & 20.06 & 20.36 & 20.21 \\
\hline A-930 & 18.91 & 19.28 & 19.32 & 19.15 & 18.84 & 19.08 & 18.87 & 19.75 & 18.78 & 18.87 & 18.81 & 18.81 & 19.66 & 18.95 & 19.35 & 19.05 \\
\hline A-908 & 18.89 & 18.99 & 18.91 & 18.92 & 18.75 & 18.84 & 18.66 & 18.73 & 18.68 & 18.74 & 18.75 & 18.72 & 18.76 & 18.81 & 19.02 & 18.88 \\
\hline A-918 & 18.03 & 18.07 & 18.16 & 18.04 & 17.76 & 17.99 & 17.71 & 18.30 & 17.71 & 17.74 & 17.76 & 17.77 & 18.15 & 17.96 & 18.12 & 17.96 \\
\hline A-921 & 18.51 & 18.64 & 17.69 & 18.54 & 17.95 & 18.22 & 18.37 & 18.12 & 18.15 & 18.26 & 17.95 & 18.00 & 18.05 & 17.93 & 18.52 & 18.03 \\
\hline \multicolumn{17}{|c|}{ Pantanal biome } \\
\hline A-901 & 14.18 & 14.35 & 11.59 & 12.66 & 15.25 & 12.58 & 15.38 & 15.63 & 14.58 & 15.27 & 12.75 & 15.28 & 15.32 & 12.66 & 14.97 & 12.49 \\
\hline
\end{tabular}




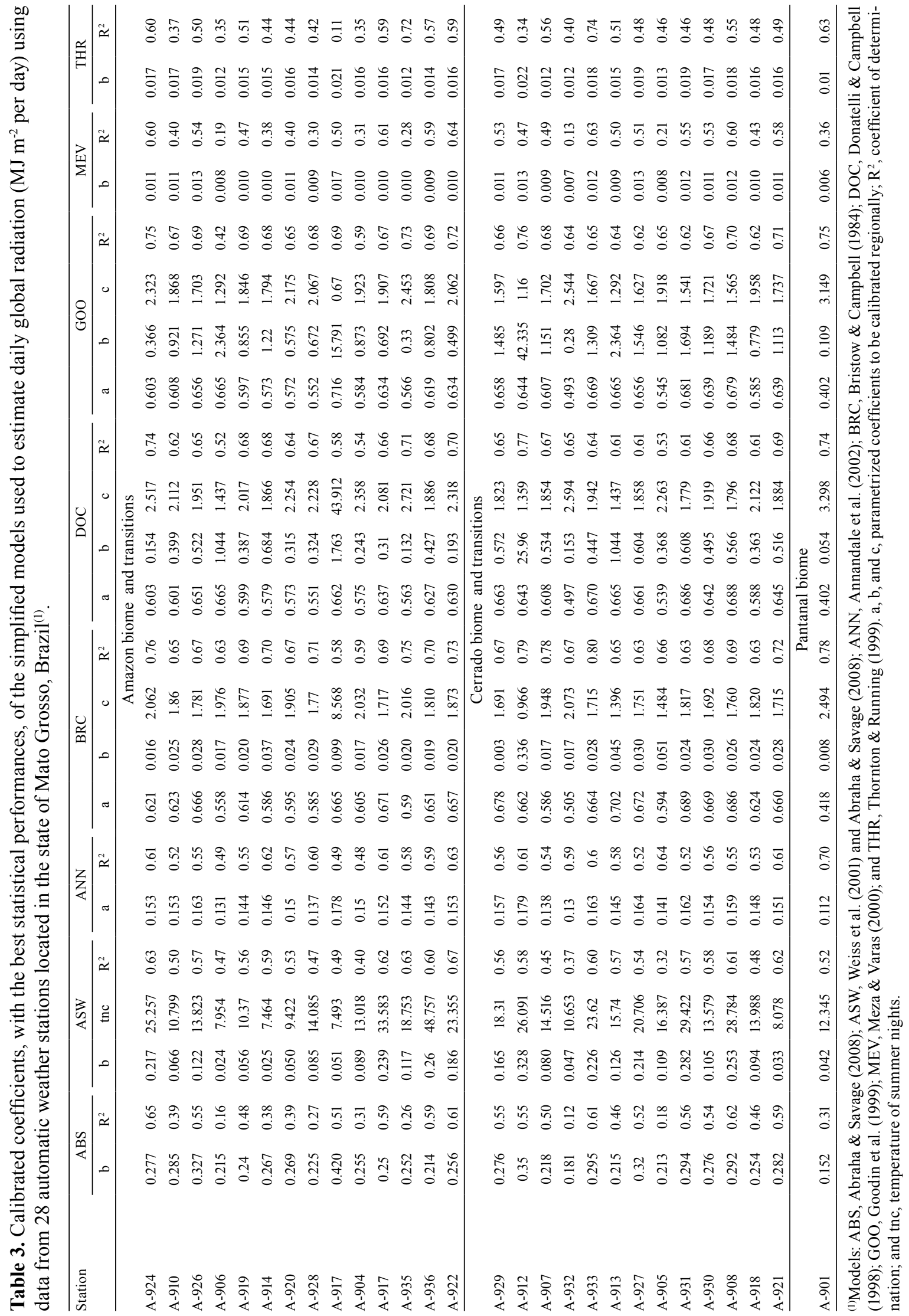




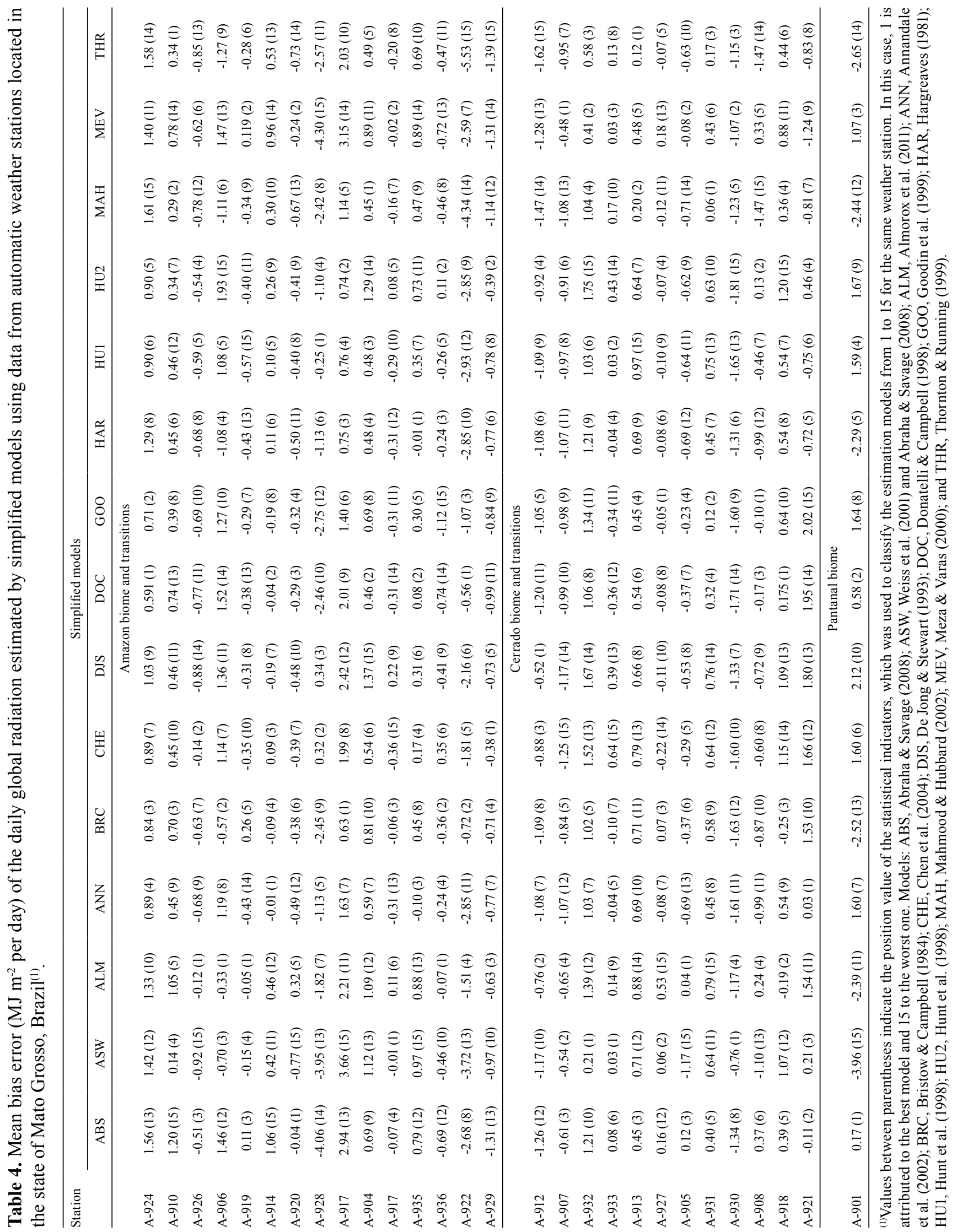




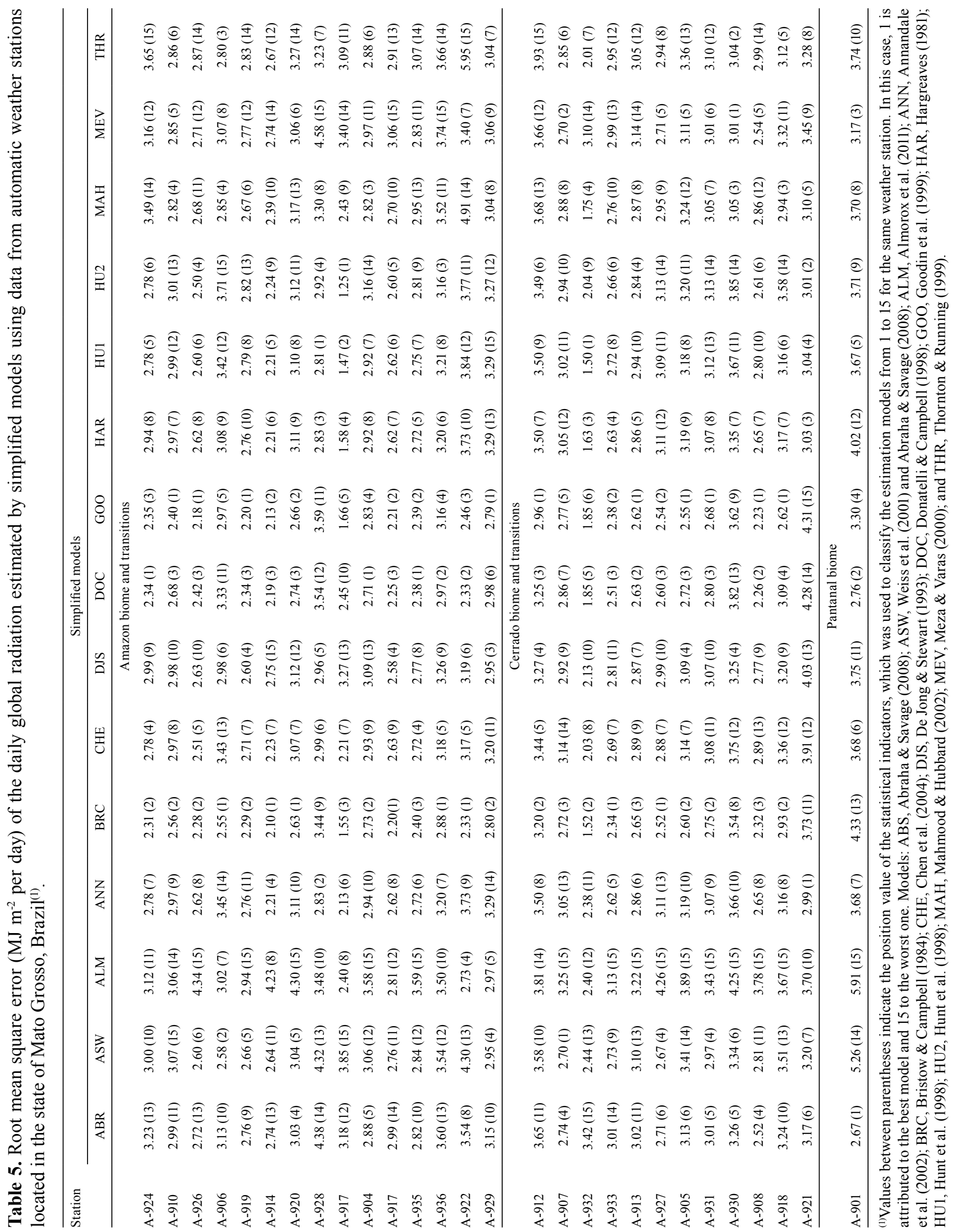




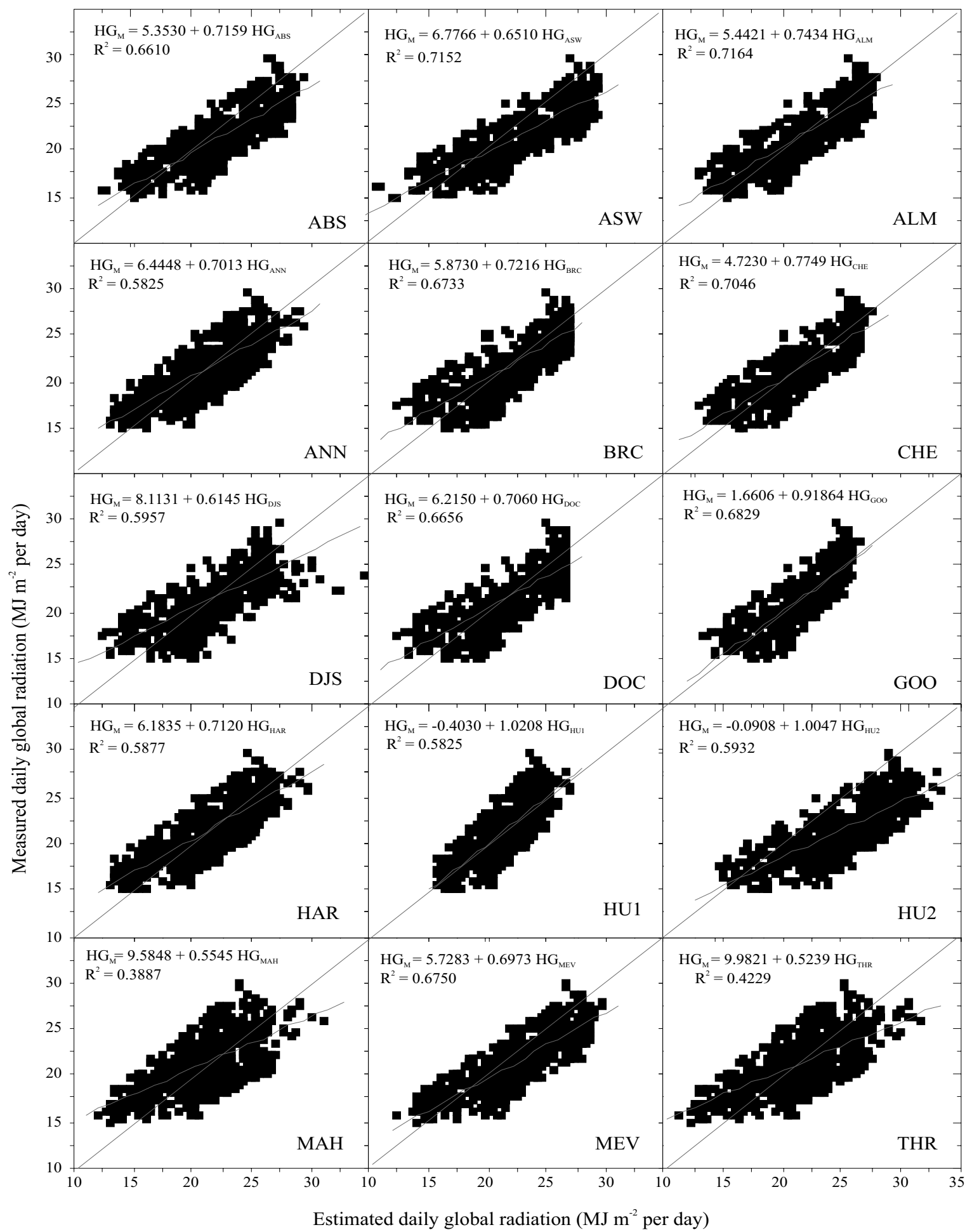

Figure 2. Correlations between the daily global radiation $(\mathrm{HG})$ measured and estimated by simplified models using data from the automatic weather station A-917 of the municipality of Sinop, located in the Amazon biome, in the state of Mato Grosso, Brazil. Models: ABS, Abraha \& Savage (2008); ASW, Weiss et al. (2001) and Abraha \& Savage (2008); ALM, Almorox et al. (2011); ANN, Annandale et al. (2002); BRC, Bristow \& Campbell (1984); CHE, Chen et al. (2004); DJS, De Jong \& Stewart (1993); DOC, Donatelli \& Campbell (1998); GOO, Goodin et al. (1999); HAR, Hargreaves (1981); HU1, Hunt et al. (1998); HU2, Hunt et al. (1998); MAH, Mahmood \& Hubbard (2002); MEV, Meza \& Varas (2000); and THR, Thornton \& Running (1999). 


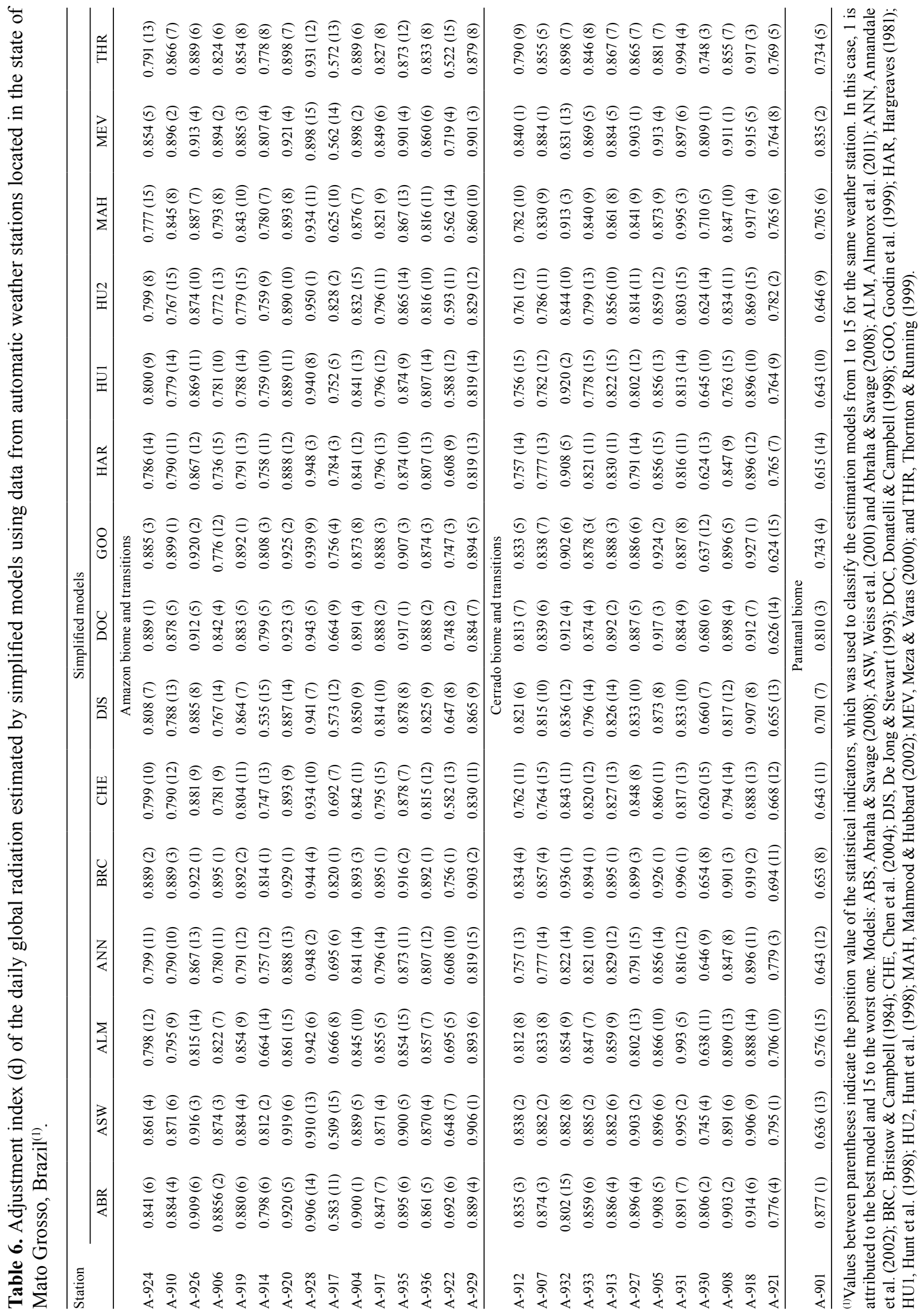


and GOO, respectively, especially BRC for the Amazon region ( $80 \%$ of the AWS); however, both models showed similar values for the Cerrado conditions. For the Cuiabá region (Pantanal-Cerrado transition), the ABS model stood out, with an overestimation of $0.17 \mathrm{MJ} \mathrm{m}^{-2}$ per day, scatterings of $2.67 \mathrm{MJ} \mathrm{m}^{-2}$ per day, and adjustments of $87.7 \%$. These results corroborate those obtained by Silva et al. (2012), who observed that Bristow \& Campbell was one of the most accurate simplified models for the state of Minas Gerais.

\section{Conclusions}

1. Biomes can be applied in simplified estimation models, based only on air temperature, to estimate the global radiation for the state of Mato Grosso, Brazil, using data from automatic weather stations.

2. The parametric coefficients used in the original models increase the average errors of the estimates, indicating the need for regional calibrations.

3. The best statistical performance in estimating the global radiation for the state of Mato Grosso, Brazil, is obtained by the Bristow \& Campbell (1984) and Goodin et al. (1999) models.

\section{Acknowledgments}

To Instituto Nacional de Meteorologia (Inmet), for making data available; and to Conselho Nacional de Desenvolvimento Científico e Tecnológico (CNPq, process No. 142210/2009-9), for scholarship granted.

\section{References}

ABRAHA, M.G.; SAVAGE, M.J. Comparison of estimates of daily solar radiation from air temperature range for application in crop simulations. Agricultural and Forest Meteorology, v.148, p.401-416, 2008. DOI: 10.1016/j.agrformet.2007.10.001.

ALMOROX, J.; HONTORIA, C.; BENITO, M. Models for obtaining daily global solar radiation with measured air temperature data in Madrid (Spain). Applied Energy, v.88, p.1703-1709, 2011. DOI: 10.1016/j.apenergy.2010.11.003.

ANNANDALE, J.G.; JOVANOVIC, N.Z.; BENADÉ, N.; ALLEN, R.G. Software for missing data error analysis of Penman-Monteith reference evapotranspiration. Irrigation Science, v.21, p.57-67, 2002. DOI: $10.1007 / \mathrm{s} 002710100047$.

ANTONANZAS-TORRES, F.; SANZ-GARCIA, A.; MARTÍNEZ-DE-PISÓN, F.J.; PERPIÑAN-LAMIGUEIRO, O. Evaluation and improvement of empirical models of global solar irradiation: case study northern Spain. Renewable Energy, v.60, p.604-614, 2013. DOI: 10.1016/j.renene.2013.06.008.
BADESCU, V. Assessing the performance of solar radiation computing models and model selection procedures. Journal of Atmospheric and Solar-Terrestrial Physics, v.105-106, p.119134, 2013. DOI: 10.1016/j.jastp.2013.09.004.

BESHARAT, F.; DEHGHAN, A.A.; FAGHIH, A.R. Empirical models for estimating global solar radiation: a review and case study. Renewable and Sustainable Energy Reviews, v.21, p.798821, 2013. DOI: 10.1016/j.rser.2012.12.043.

BOJANOWSKI, J.S.; VRIELING, A.; SKIDMORE, A.K. Calibration of solar radiation models for Europe using Meteosat Second Generation and weather station data. Agricultural and Forest Meteorology, v.176, p.1-9, 2013. DOI: 10.1016/j. agrformet.2013.03.005.

BORGES, V.P.; OLIVEIRA, A.S. de; COELHO FILHO, M.A.; SILVA, T.S.M. da; PAMPONET, B.M. Avaliação de modelos de estimativa da radiação solar incidente em Cruz das Almas, Bahia. Revista Brasileira de Engenharia Agrícola e Ambiental, v.14, p.74-80, 2010. DOI: 10.1590/S1415-43662007000300008.

BRISTOW, K.L.; CAMPBELL, G.S. On the relationship between incoming solar radiation and daily maximum and minimum temperature. Agricultural and Forest Meteorology, v.31, p.159166, 1984. DOI: 10.1016/0168-1923(84)90017-0.

CHEN, R.; ERSI, K.; YANG, J.; LU, S.; ZHAO, W. Validation of five global radiation models with measured daily data in China. Energy Conversion and Management, v.45, p.1759-1769, 2004. DOI: 10.1016/j.enconman.2003.09.019.

DE JONG, R.; STEWART, D.W. Estimating global solar radiation from common meteorological observations in western Canada. Canadian Journal of Plant Science, v.73, p.509-518, 1993. DOI: 10.4141/cjps93-068.

DONATELLI, M.; CAMPBELL, G.S. A simple model to estimate global solar radiation. In: CONGRESS OF THE EUROPEAN SOCIETY FOR AGRONOMY, 5., 1998, Nitra. Proceedings... [Colmar?]: European Society for Agronomy, 1998. v.2, p.133-134.

DUMAS, A.; ANDRISANI, A.; BONNICI, M.; GRADITI, G.; LEANZA, G.; MADONIA, M.; TRANCOSSI, M. A new correlation between global solar energy radiation and daily temperature variations. Solar Energy, v.116, p.117-124, 2015. DOI: 10.1016/j.solener.2015.04.002.

GOMES, F.J.D.; SANCHES, L.; ALVES, M. de C.; NOGUEIRA, M.C. de J.A.; NOGUEIRA, J. de S. The relationship between meteorological variables and clearness index for four urban/ suburban areas of Brazilian cities. Journal of Environmental Science and Engineering B, v.1, p.890-900, 2012.

GOODIN, D.G.; HUTCHINSON, J.M.S.; VANDERLIP, R.L.; KNAPP, M.C. Estimating solar irradiance for crop modelling using daily air temperature data. Agronomy Journal, v.91, p.845851, 1999. DOI: 10.2134/agronj1999.915845x.

GUEYMARD, C.A.; MYERS, D.R. Evaluation of conventional and high-performance routine solar radiation measurements for improved solar resource, climatological trends, and radiative modeling. Solar Energy, v.83, p.171-185, 2009. 
HARGREAVES, G.H. Responding to tropical climates. In: SLATER, L.E. (Ed.). Food and Climate Review 1980-81. Boulder: Aspen Institute for Humanistic Studies, 1981. p.29-32.

HUBER, I.; BUGLIARO, L.; PONATER, M.; GARNY, H.; EMDE, C.; MAYER, B. Do climate models project changes in solar resources? Solar Energy, v.129, p.65-84, 2016. DOI: 10.1016/j.solener.2015.12.016.

HUNT, L.A.; KUCHAR, L.; SWANTON, C.J. Estimation of solar radiation for use in crop modelling. Agricultural and Forest Meteorology, v.91, p.293-300, 1998. DOI: 10.1016/S01681923(98)00055-0.

LIU, X.; MEI, X.; LI, Y.; WANG, Q.; JENSEN, J.R.; ZHANG, Y.; PORTER, J.R. Evaluation of temperature-based global solar radiation models in China. Agricultural and Forest Meteorology, v.149, p.1433-1446, 2009. DOI: 10.1016/j.agrformet.2009.03.012.

MAHMOOD, R.; HUBBARD, K.G. Effect of time of temperature observation and estimation of daily solar radiation for the Northern Great Plains, USA. Agronomy Journal, v.94, p.723-733, 2002. DOI: 10.2134 /agronj2002.7230.

MEZA, F.; VARAS, E. Estimation of mean monthly solar global radiation as a function of temperature. Agricultural and Forest Meteorology, v.100, p.231-241, 2000. DOI: 10.1016/S01681923(99)00090-8.

MOURA, A.D.; LUCAS, E.W.M.; RODRIGUES, J.E.; REZENDE, J.M. de. Nota Técnica $n^{0}$ 001/2011/SEGER/LAIME/CSC/ INMET: rede de estações meteorológicas automáticas do Inmet. [Brasília]: Inmet, 2011. 11p.

SILVA, C.R. da; SILVA, V.J. da; ALVES JÚNIOR, J.; CARVALHO, H. de P. Radiação solar estimada com base na temperatura do ar para três regiões de Minas Gerais. Revista Brasileira de Engenharia Agrícola e Ambiental, v.16, p.281288, 2012. DOI: 10.1590/S1415-43662012000300008.
SOUZA, A.P. de; MOTA, L.L. da; ZAMADEI, T.; MARTIM, C.C.; ALMEIDA, F.T. de; PAULINO, J. Classificação climática e balanço hídrico climatológico no estado de Mato Grosso. Nativa, v.1, p.34-43, 2013. DOI: 10.14583/2318-7670.v01n01a07.

SOUZA, A.P.; ESCOBEDO, J.F.; DAL PAI, A.; GOMES, E.N. Estimativas das componentes da radiação solar incidente em superfícies inclinadas baseadas na radiação global horizontal. Revista Brasileira de Engenharia Agrícola e Ambiental, v.15, p.277-288, 2011. DOI: 10.1590/S1415-43662011000300009.

TEKE, A.; YILDIRIM, H.B.; ÇELIK, Ö. Evaluation and performance comparison of different models for the estimation of solar radiation. Renewable and Sustainable Energy Reviews, v.50, p.1097-1107, 2015. DOI: 10.1016/j.rser.2015.05.049.

THORNTON, P.E.; RUNNING, S.W. An improved algorithm for estimating incident daily solar radiation from measurements of temperature, humidity, and precipitation. Agricultural and Forest Meteorology, v.93, p.211-228, 1999. DOI: 10.1016/S01681923(98)00126-9.

TIBA, C. (Coord.). Atlas solarimétrico do Brasil: banco de dados terrestres. Recife: Editora Universitária da UFPE, 2000. 111p.

VEERABOINA, P.; GUDURI, G.Y. Analysis of yearly solar radiation by using correlations based on ambient temperature: India. Sustainable Cities and Society, v.11, p.16-21, 2014. DOI: 10.1016/j.scs.2013.

WEISS, A.; HAYS, C.J.; HU, Q.; EASTERLING, W.E. Incorporating bias error in calculating solar irradiance: implications for crop yield simulations. Agronomy Journal, v.93, p.1321-1326, 2001. DOI: 10.2134/agronj2001.1321.

YACEF, R.; MELLIT, A.; BELAID, S.; ȘEN, Z. New combined models for estimating daily global solar radiation from measured air temperature in semi-arid climates: application in Ghardaïa, Algeria. Energy Conversion and Management, v.79, p.606-615, 2014. DOI: 10.1016/j.enconman.2013.12.057.

Received on March 16, 2016 and accepted on December 22, 2016 